\title{
The Expressive Urban Cultures Exposed in Vulgar Song Lyrics (The Study of Language Sexism)
}

\author{
Dewi Kusumaningsih, Wiwik Darmini, S Suparmin, Sukarno, Farida Nugrahani
}

Indonesian Language and Literature Department University of Veteran Bangun Nusantara, Sukoharjo, Central Java, Indonesia

Dewikusumaningsih71@gmail.com

\begin{abstract}
The article explored the phenomenon of expressive urban cultures which was featured in Indonesian song lyrics and potentially contained vulgarism. It utilized a Qualitative Approach in an attempt to discover the expressive urban cultures in vulgar song lyrics. The data source derived from several Indonesian songs from various genres (especially pop and dangdut). Meanwhile, the data consisted of the lingual units of vulgar speeches in the forms of words, phrases, and clauses. A Content Analysis was deployed as the data collecting technique. The findings revealed that 1) the phenomenon of expressive urban cultures had led to the common use of vulgar language in Indonesian song lyrics; 2) women were negatively exposed through vulgarism in all Indonesian songs from the data source. The Linguistics forms of the expressive urban cultures consisted of words, phrases, and clauses. In regards to the negative exploitation, the women's position mostly appeared in multiple black labels, for instance as kept women, sex workers, paramours, harlots, second wives, evil women, etc.
\end{abstract}

Keywords: Vulgar Language; Expressive Culture; Gender Exploitation; Song Lyric.

\section{INTRODUCTION}

The urban cultures derive from the urban population's lifestyles that tend to prioritize rationality, logic, heterogeneity, individualism, expression, and consideration in taking decision [1]-[4]. They are transparent in expressing their language for greetings, pronouns, nouns, etc. The growth of urban cultures have created a number of social phenomena, which include slangs and vulgar language. Mojela explained that the urban slangs had been considered as a social prestige among South African teenagers [5], as the terminology offered a great influence on the daily usage of their indigenous languages. The phenomenon is similar to Indonesian urban population that tends to apply multi-language features in their daily life, such as the mix of Indonesian and foreign Language in particular situations. Saddhono and D. Sulaksono mentioned it as Indoglish that commonly appears as a public utterance and functions as a prestigious communal identity [6]. 
The use of vulgar language has thrived in Indonesian song lyrics [7]-[10]. It is rather like a two-sided coin, one of which describes the socio-cultural life that has inspired the songwriters. Coates [11] explained that sexism covered the social issues from the reflection of human's experiences.

In more detail exploration, most of the vulgar song lyrics indicate the gender exploitation due to an apparent exposure of women's position from a negative side. A number of studies concerning the gender-related issues [12]-[16] had also discussed the similar topic. In the Linguistics coverage, the gender bias is appealing to explore due to the woman exploitation as its main context to analyze. It directs to a gender discrepancy through the description of women as the sexual objects through a rude, lewd, and sordid representation, such as sirens, paramours, kept women, and harlots. Meanwhile, men are mostly symbolized positively as the merciful responsible lover and protector.

"Vulgar" is an adjective that briefly refers to a vile, sordid, and extremely impolite attitude [17]. In particular, vulgarism explains an immoral act that deviates the social norms. The existing vulgar language in Indonesian song lyrics has implied the use of impolite language for entertainment that will lead to an abnormal perspective across the conventions. Moreover, the forms of the vulgar language in the lyrics expose women dominantly. As the impact, a particular song can lose its aesthetics of archaic style and eventually becomes a vulgar media to express the swearing swear and curse that the writers speak out since they ignore the politeness principles. The use of vulgar language underlies the notion of expressive urban cultures.

\section{METHODOLOGY}

The study applied a Descriptive Qualitative method. The data consisted of the lingual units, which include phonemes, phrases, and clauses featured in several Indonesian pop and dangdut song lyrics. It adopted a purposive sampling technique in an attempt to analyze the vulgar speeches in Indonesian pop and dangdut songs. To obtain a more in-depth analysis, the study did not limit the number of data source, however, it framed the objectives to reveal the vulgar language from various Linguistics structures. The data analysis technique applied a Contextual Analysis aiming to describe the concept of the relevant cultural phenomenon from the Linguistics scope [18]-[20]. Meanwhile, the data source was gained from online and printed sources. The stages of online data source collection comprised of the activities of downloading the songs from YouTube.com and proceeding to the data transcription based on Indonesianstandardized spelling. Meanwhile, the printed data source collection took a simpler step through a direct analysis of the vulgar language used in the songs.

The article referred to a Contextual Analysis model in order to visualize the relevant cultural phenomenon. It stood as an inductive analysis through consecutive procedures, which include simultaneous observation; classification through matrix and tables; interactive mapping; complex interpretation for the mapping of theories, secondary data, and context; and cultural perspective exploration [20].

\section{FINDINGS}

\subsection{The Forms of Vulgar Language Found in Indonesian Songs}


The findings discovered the use of vulgar language in the forms of stems, compound words, repetitions, and clauses. In the coverage of Indonesian Linguistics, the formation of compound words mainly explains an action that relates to the referent. Meanwhile, stems are formulated through root + affix, the affixes of which consist of prefix (di-;ber-; me-), circumfix (di-in), and suffix (-an; -ku; -mu). Most of the affixes were in the form of prefix di- and circumfix di-in that indicated passive voices and explained women as the object of exploitation. In particular, the circumfix di-in derives from Jakarta dialect which is generally spoken by teenagers as their lingua franca.

The vulgarism relates to the language style that dominantly describes the sexual tendency. In term of gender exploitation, the affixes create a sense that women become the object of an action for someone's desire. Table 1 shows several vulgar language structures in the forms of stems.

Table 1. The Vulgar Language Structures in The Forms of Stems Stem Patterns Vulgar Language Structures

The use of repetitions which consisted of original repetitive and affixed repetitive words shared larger portion compared to the use of roots and compound words. Table 2 represents the findings of vulgar language in the forms of repetitions.

Table 2. The Vulgar Language Structures in The Forms of Repetitions Repetition Patterns root - root

di- + root - root

root - root +- an
Vulgar Language Structures

Pengen-pengen, remang-remang, pegangpegang, elus-elus, belai-belai Digoyang-goyang, diputer-puter Sayang-sayangan, mesra-mesraan, ciumciuman, peluk-pelukan

Repetition explains a concept of a repetitive thing or event, which is either based on its quantity or quality. Batu-batu, meja-meja, and gadis-gadis are the instances for the quantitative repetitions, meanwhile the qualitative repetitions generally occur with the repetitive verbs. Table 2 shows the original repetitions and affixed repetitions, of which remang-remang, pengenpengen, pegang-pegang, elus-elus, and belai-belai belong to the original repetitions. Meanwhile, the passive-voiced pattern di- + root - root dominates the findings in the forms of affixed repetitions that imply the women's position as the object of a sexual action. Differently, the pattern root - root + -an represents a reciprocal activity, such as sayang-sayangan, mesramesraan, cium-ciuman, and peluk-pelukan. It indicates that women are also described as the parties that enjoy the sexual intercourse, in spite of their position as the object of exploitation. 
The compound words were also found in several parts of the Indonesian song lyrics. Table 3 shows the findings of vulgar language in the forms of compound words. 
Table 3. The Vulgar Language Structures in The Forms of Compound Words Compound Word Patterns Vulgar Language Structures

Compound Word $(\mathrm{CP})$ Cewek gampangan, cewek murahan, cewek kampungan, geboy mujair, suami orang, lelaki buaya, lubang buaya, kekasih gelapku

The vulgar language in the forms of compound words consists of several patterns, which include $\mathrm{CP}+-\mathrm{an} ; \mathrm{CP}+-\mathrm{ku}$; and $\mathrm{CP}$ independently. However, the pattern shared less portion than others. In contrast, the pattern $\mathrm{CP}+-$ an could indicate the woman exploitation through several terms of cewek murahan, cewek gampangan, and cewek kampungan that point out a vivid sense of disgrace. In particular, murah + -an similarly means as "twopenny" and kampung +- an means as "rustic".

The vulgar language also appeared in the forms of phrases, even if in the small numbers. Table 4 shows the findings of vulgar language in the forms of phrases.

Table 4. The Vulgar Language Structures in The Forms of Phrases

\begin{tabular}{cc}
\hline Phrase Patterns & Vulgar Language Structures \\
\hline Noun Phrase & Wanita penjaja cinta \\
\hline Verb Phrase & - \\
\hline Complement Phrase & Hamil duluan, ada yang panjang, ada yang \\
& pendek, ada yang lentur, ada yang bengkok, \\
& ada yang dalam, ada yang cetek, ada yang \\
& luwes, ada yang sempit \\
\hline
\end{tabular}

Similar to $\mathrm{CP}$, the findings only shared a small portion for phrases, from which the data only contain noun phrase and complement phrases. The phrases shown in Table 4 symbolize the vulgarism of gender exploitation. The woman exploitation is represented through the noun phrase wanita penjaja cinta that apparently exposes a profession of a female sex worker. Meanwhile, the complement phrases of the findings describe male and female genital organs, such as hamil duluan, ada yang panjang, ada yang pendek, ada yang lentur, ada yang bengkok, ada yang dalam, ada yang cetek, ada yang luwes, and ada yang sempit.

Several clauses of the song lyrics also convey the vulgarism. As clause contains verb in its feature, the sense of sexual desire is vividly presented. Table 5 shows the findings of vulgar language in the forms of clauses.

Tabel 5. The Vulgar Language Structures in The Forms of Clauses

\begin{tabular}{cc}
\hline Clause Patterns & Vulgar Language Structures \\
\hline Kau tikam aku dengan cintamu \\
Melepaskan hasrat dirimu \\
Kamu sering dipakai kakakku \\
Kamu sering dipakai adikku \\
Aku suka susumu \\
Aku suka anumu \\
\hline
\end{tabular}


Clause structures relatively have a considerable amount as the representation of songwriters' imagination in depicting women as the negative object. Clauses even play a dominant role in establishing a detail narration of sexual expression through the lyrics due to their predicative function in explaining a verb or complement's position. All of the clauses, which include aku suka susumu, aku suka апитu, and kamu sering dipakai kakakku describe the women's position as the object of sexual exploitation through a salacious sense.

\section{DISCUSSION}

Previously, Omar Sharif [13] had studied the use of particular vocabularies that indicate gender exploitation. He revealed that sexist language could contain a bias that seemingly put a favor to one gender and discriminate the other. The phenomenon mostly placed men at higher status than women. Nowadays, the gender-stereotyped vocabularies have also been considered as the form of gender exploitation.

The study offers a different perspective from Shamsuddin who claimed that fairer solution in describing human based on their gender is urgently demanded to educate children the genderbased norms. Children are considered as the object for gender-based education due to their learning instruments that potentially may create gender bias [12]. Meanwhile, Sarah had analyzed top ten songs in 2013 from six genres, which included rap, hip-hop, country, rock, alternative, and dance. She conveyed five themes of sexism, which included women's role in traditional perspective, women's lower status compared to men's, women as the object, women as the stereotype, and violence toward women [21].

\section{CONCLUSION}

The article concludes that gender exploitation had particularly exposed women as the object of vulgar description through song lyrics. The exposure appears in various Linguistics forms which consist of words, phrases, and clauses. The selection of vulgar language relates to the language formation, such as compound words that mostly stand from the pattern $d i-+$ root. As the indicator of passive voice, the prefix $d i$ - briefly depicts a context that women are supposed as the object of an action that leads to the exploitation.

\section{REFERENCES}

[1] M. N. Islami, "Rerensentasi Masyarakat Urban Jakarta dalam Film Jakarta Maghrib.," Commonline Dep. Komun., vol. 2, no. 2, pp. 47-60, 2009.

[2] R. W. Emerson and F. Kang, "Youth, creativity and urban life: insights from classics Frederick Kang'ethe Iraki," Africa (Lond)., vol. 3, no. 1, pp. 284-297, 2011.

[3] R. Marnita, "Pergeseran Bahasa dan Identitas Sosial dalam Masyarakat Minangkabau Kota: Studi Kasus di Kota Padang," 2011.

[4] R. S. Putri, “Gaya Hidup Kaum Urban Dalam Iklan 3 Three,” Universitas Sultan Ageng Tirtayasa, 2014.

[5] V. M. Mojela, "The cause of urban slang and its effect on the development of the Northern Sotho lexicon," Lexikos, vol. 12, no. July 2000, pp. 201-210, 2002.

[6] K Saddhono and D Sulaksono, "Indoglish as adaptation of english to Indonesian: change of society in big cities of Indonesia," in IOP Conference Series: Earth and Environmental Science 126 (2018) 012092, 2018. 
[7] M. Pilotti, J. Almand, and M. Martinez, "Taboo Words in Expressive Language : Do Sex and Primary Language Matter?," Am. Int. J. Contemp. Res., vol. 2, no. 2, pp. 17 26, 2012.

[8] A. Mulac, "Effects Of Obscene Language Upon Three Dimensions Of Listener Attitude," Commun. Monogr., 1976.

[9] L. Hartmann, "Some Uses of Dirty Words by Children," J. Am. Acad. Child Psychiatry, vol. 12, no. 1, pp. 108-122, 1973.

[10] R. Trager and Y. Obata, "Obscenity Decisions in the Japanese and United States Supreme Courts: Cultural Values in Interpreting Free Speech,” U.C. Davis J. Int. Law Policy, vol. 10, 2004.

[11] J. Coates, Women, Men and Language A Sociolinguistic Account of Gender Difference in Language, 3rd ed. London and New York: Routlegde, 2016.

[12] C. M. Shamsuddin and B. A. Hamid, "Representational Meanings of Gender Stereotyped Professional Occupation Images in Selected Malaysian English Language Textbooks," 3L Southeast Asian J. English Lang. Stud., vol. 23, no. 4, pp. 128-142, 2017.

[13] C. Omar Sharif, "Sexism and Variations in the Use of Language," Int. J. Adv. Res, vol. 5, no. 12, pp. 1136-1144, 2017.

[14] X. Lei, “Sexism in Language," J. Lang. Linguist., vol. 5, no. 1, pp. 87-94, 2006.

[15] S. Mills, "Language and sexism," in Language and Sexism, 2008.

[16] L. Coffey, "Review Gender Matters : Feminist Linguistic Analysis Sara Mills (2012)," Gend. Lang., vol. 7, no. 3, pp. 405-408, 2013.

[17] Tim Penyusun Kamus Pusat Pembinaan dan Pengembangan Bahasa, Kamus Besar Bahasa Indonesia. Jakarta: Balai Pustaka, 1989.

[18] Sudaryanto, Metode dan Aneka Teknik Analisis Bahasa: Pengantar Penelitian Wahana Kebudayaan Secara Linguistis. Yogyakarta: Sanata Dharma University Press, 2015.

[19] D. E. Subroto, Pengantar Metoda Penelitian Linguistik Struktural, 1st ed. Surakarta: UNS Press, 1992.

[20] R. Santosa, Metode Penelitian Kualitatif Kebahasaan, 1, April 2 ed. UNS Press, 2017.

[21] S. Neff, "Sexism Across Musical Genres : A Comparison," Honor. Theses, 2014. 